\title{
Keragaman Nukleotida Gen Lcy-b (Lycopene beta cyclase) Kultivar Tomat Betavila F1, Fortuna F1 dan Tymoti F1
}

\author{
MUHAMMAD THOIFUR IBNU FAJAR ${ }^{1}$, PURNOMO $^{2}$, NIKEN SATUTI NUR HANDAYANI ${ }^{1}$ \\ ${ }^{1}$ Laboratorium Genetika, Fakultas Biologi, Universitas Gadjah Mada \\ ${ }^{2}$ Laboratorium Sistematik Tumbuhan, Fakultas Biologi, Universitas Gadjah Mada \\ J1. Teknika Selatan, Sekip Utara, Sleman, Yogyakarta 55281 \\ email: ibnu4040@gmail.com
}

\begin{abstract}
Tomato has three lycopene gene, namely lycopene beta cyclase (Lcy-b), lycopene beta-cyclase kromoplas $(C y c-b)$ and lycopene epsilon cyclase (Lcy-e). Lcy-b gene can be used as determinant of phylogenetic relationship between tomato and chili. This research aims to know phylogenetic relationship among tomatoes cultivar, namely Betavila F1, Fortuna F1 and Tymoti F1, then phylogenetic relationship between these tomatoes cultivar and tomatoes sequences Kristin KC140137.1, Darsirius KC140135.1, Pennellii XM 015217853.1, Villosum KP313876.1 and outgroup Capsicum annuum GU085266.1. Besides that, this research also aims to know the difference of nucleotide among tomatoes cultivar and the others tomato sequences and the outgroup Capsicum annuum based of alignment result. PCR (Polymerase Chain Reaction) method and NCBI primer design used to isolate $L c y-b$ gene. Acquired sequences were analyzed by Mega 6 and Clustal $X$ softwares. The result of phylogenetic relationship among tomatoes cultivar showed Betavila Fl cultivar closely related to Tymoti F1 cultivar and Fortuna F1 cultivar closely related to Tymoti F1 cultivar. Phylogenetic relationship between tomatoes cultivar and the other tomatoes sequences showed Fortuna F1 cultivar closely related to Darsirius cultivar and varieties Pennellii, Betavila F1 cultivar distantly related to the other tomatoes sequences, and Tymoti F1 cultivar closely related to Kristin cultivar. The difference of nucleotide were found at Pennellii tomato that is 1 nucleotide with transition mutation, found at Villosum tomato that are 12 nucleotides with transition and transversion mutation, and found at Capsicum annuum that are 16 nucleotides with transition and transversion mutation. Phylogenetic relationship using $L c y-b$ gene expected to be used as a transgenic strategy to modify carotenoid content that improves tomatoes nutrition.
\end{abstract}

Keywords: Fortuna F1, lycopene beta-cyclase gene, phylogenetic relationships, tomato Betavila F1, Tymoti F1

\section{INTISARI}

Tomat memiliki tiga gen lycopene yakni lycopene beta cyclase (Lcy-b), lycopene beta-cyclase kromoplas $(C y c-b)$ dan lycopene epsilon cyclase (Lcy-e). Gen Lcy-b dapat digunakan sebagai penentu hubungan kekerabatan yang jauh antara tomat dengan cabai. Penelitian ini pertama bertujuan untuk mengetahui hubungan kekerabatan di antara kultivar tomat Betavila F1, Fortuna F1 dan Tymoti F1 dan hubungan kekerabatan ketiga kultivar tomat tersebut dengan sekuen tomat Kristin KC140137.1, Darsirius KC140135.1, Pennellii XM 015217853.1, Villosum KP313876.1 dan outgroup Capsicum annuum GU085266.1. Tujuan penelitian kedua untuk mengetahui perbedaan basa nukleotida di antara ketiga kultivar tomat lokal dengan sekuen tomat lain tersebut dan outgroup Capsicum annuum berdasarkan hasil alignment. Metode PCR (Polymerase Chain Reaction) dengan desain primer NCBI digunakan untuk mengisolasi gen $L c y-b$. Sekuen yang diperoleh dianalisis dengan menggunakan program Mega 6 dan Clustal X. Hasil kekerabatan ketiga kultivar tomat menunjukkan kultivar Betavila F1 berkerabat dekat dengan kultivar Tymoti F1 dan kultivar Fortuna Fl berkerabat dekat dengan kultivar Tymoti Fl. Kekerabatan ketiga kultivar tomat dengan sekuen tomat gene bank menunjukkan kultivar Fortuna F1 berkerabat dekat dengan kultivar 
Darsirius dan varietas Pennellii, kultivar Betavila F1 berkerabat jauh dengan sekuen tomat gene bank dan kultivar Tymoti F1 berkerabat dekat dengan kultivar Kristin. Perbedaan basa nukleotida ditemukan pada tomat Pennellii sebanyak 1 basa nukleotida mutasi transisi, 12 basa nukleotida mutasi transisi dan transversi pada tomat Villosum dan 16 basa nukleotida mutasi transisi dan transversi pada Capsicum annuum. Kekerabatan molekular dengan menggunakan gen Lcy-b diharapkan dapat dijadikan sebagai strategi transgenik untuk memodifikasi kandungan karotenoid yang meningkatkan nutrisi buah tomat.

Kata Kunci: Fortuna F1, gen lycopene beta cyclase, hubungan filogenetik, tomat Betavila F1, Tymoti F1

\section{PENDAHULUAN}

Karotenoid adalah pigmen pemberi warna pada tumbuhan yang fungsinya bagi manusia sebagai antioksidan, prekursor hormon dan fungsi bagi tumbuhan komponen penting dari organel fotosintesis. Karotenoid terakumulasi hampir di semua tipe plastida, tidak hanya di kloroplas, karotenoid ditemukan di sebagian besar jaringan dan organ tumbuhan (Howit \& Pogson, 2006). Karotenoid terakumulasi sebagai metabolit sekunder pada kromoplas menyediakan warna yang berbeda pada bunga dan buah (Ronen et al., 2000). Karotenoid merupakan molekul isoprene yang umum untuk semua jaringan fotosintesis. Karotenoid dibagi menjadi karoten hidrokarbon seperti likopen dan bkaroten dan xantofil seperti lutein (Bramley, 2012). Likopen dan lutein merupakan karotenoid penting karena sangat bermanfaat untuk memelihara kesehatan yang baik (ElRaey et al., 2013). Likopen adalah salah satu dari 600 karotenoid yang disintesis oleh tanaman dan mikroorganisme fotosintesis (Breemen \& Pajkovic, 2008).

Sintesis likopen dikontrol oleh gen Psy (phytoene synthase) dan gen Pds (phytoene desaturase) selama pematangan buah (Rosati et al., 2000). Jalur biosintesis karotenoid ditunjukkan pada Gambar 1.

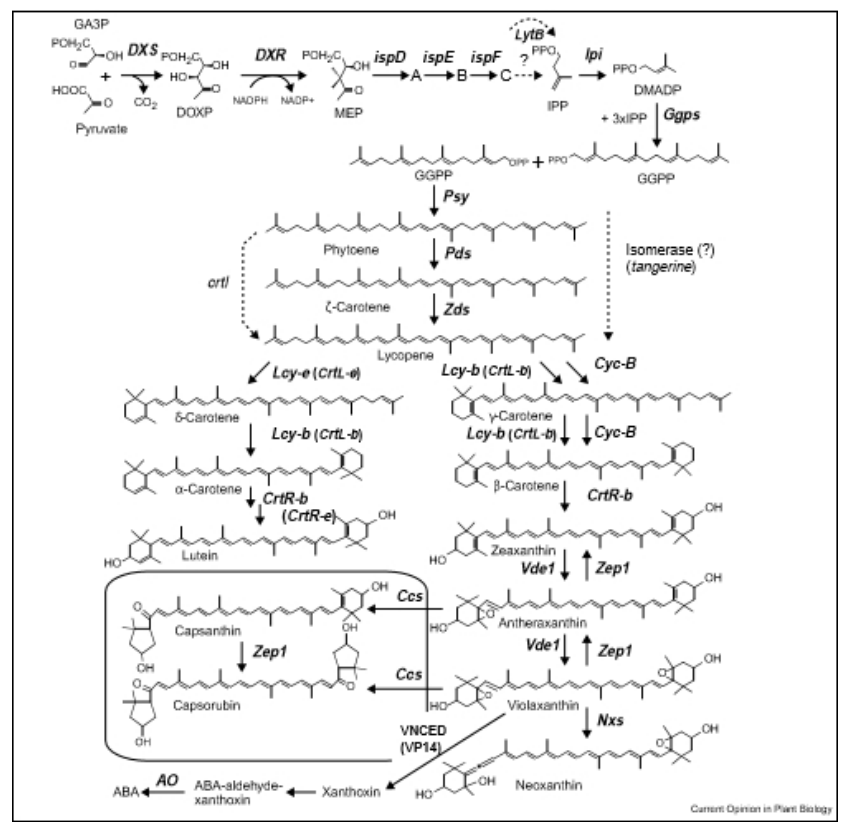

Gambar 1. Jalur biosintesis karotenoid sampai menghasilkan likopen dan gen likopen beta cyclase (Hirschberg, 2001)

Aktivitas gen $L c y$ - $b$ yang mengkode kloroplas diekspresikan di daun, bunga dan buah sampai tahap pematangan buah, aktivitas gen $C y c-b$ yang mengkode kromoplas diekspresikan di bunga dan buah sampai tahap pematangan buah (Dalal et al, 
2010) dan aktivitas gen Lcy-e yang mengkode enzim lycopene epsilon cyclase di daun dan buah (Giorio et al., 2013). Gen lycopene beta cyclase memiliki panjang $1955 \mathrm{bp}$.

Tujuan penelitian ini pertama adalah untuk mengetahui hubungan kekerabatan di antara ketiga kultivar tomat lokal dan hubungan kekerabatan ketiga kultivar tomat dengan sekuen tomat Darsirius, Kristin, Pennellii, Villosum dan outgroup Capsicum annuum kultivar Valensia. Tujuan kedua dari penelitian ini untuk mengetahui perbedaan basa nukleotida di antara kultivar tomat dan outgroup Capsicum annuum kultivar Valensia.

Pada studi sebelumnya, gen likopen ini dapat digunakan untuk merekonstruksi filogeni atau hubungan kekerabatan berbagai varietas tomat antara tomat liar dan tomat kultivar dan mengetahui perbedaan basa nukleotida yang mengalami mutasi di antara kultivar tomat. Selain itu, keberadaan gen likopen sebagai salah satunya gen chromoplast beta cyclase $(C y c-b)$ di alam berkontribusi sebagai penanda molekular yang membantu persilangan atau strategi transgenik untuk memodifikasi kandungan karotenoid dalam budidaya tomat (Araujo et al, 2007).

\section{METODE}

Isolasi DNA genom tomat. Isolasi DNA genom tomat dilakukan dengan modifikasi metode CTAB (Doyle \& Doyle 1990). Isolasi DNA genom tomat dilakukan pada sampel daun muda ketiga kultivar tomat Betavila F1, Fortuna F1 dan Tymoti F1 sebanyak $140 \mathrm{mg}$. Kemudian hasil isolasi DNA disimpan di kulkas suhu $-20^{\circ} \mathrm{C}$ sampai waktu penggunaan sebagai DNA template untuk proses PCR.

Amplifikasi Gen $\mathbf{L c y}$-b dengan metode PCR. Amplifikasi DNA gen $L c y-b$ tomat dilakukan berdasarkan prosedur Kappa dengan komponen reaksi PCR tersaji pada Tabel 1. Amplifikasi DNA gen $L c y-b$ menggunakan pasangan primer forward dan reverse. Runutan nukleotida untuk primer $L c y-b \quad$ forward adalah AGTGGAAGAGCACCCCTTTG, sedangkan untuk primer $L c y-b$ reverse adalah TACTGGAAGTGGACCACCCA. Pasangan primer tersebut menghasilkan panjang produk amplifikasi sebesar 301 pasang basa yang tersaji pada Gambar 2.

Tabel 1. Komponen reaksi PCR

\begin{tabular}{lll}
\hline Komponen & Volume & Konsentrasi final \\
\hline 2x KAPA2G Fast Readymix ${ }^{2}$ & $12,5 \mu \mathrm{l}$ & $1 \mathrm{X}$ \\
Primer forward & $1,25 \mu \mathrm{l}$ & $0,5 \mu \mathrm{M}$ \\
Primer reverse & $1,25 \mu \mathrm{l}$ & $0,5 \mu \mathrm{M}$ \\
ddH2O PCR & $8 \mu \mathrm{l}$ & $\mathrm{N} / \mathrm{A}$ \\
Template DNA & $2 \mu \mathrm{l}$ & $10 \mu \mathrm{g} / \mathrm{ml}$ \\
Total Volume PCR mix & $25 \mu \mathrm{l}$ & \\
\hline
\end{tabular}

Kondisi reaksi amplifikasi yang dilakukan menurut prosedur Kappa dan suhu annealing TM primer gen $L c y-b$ adalah sebagai berikut: 35 siklus terdiri dari predenaturasi $95^{\circ} \mathrm{C}$ selama 3 menit, denaturasi $95^{\circ} \mathrm{C}$ selama 15 detik, annealing suhu $53^{\circ} \mathrm{C}$ selama 15 detik, extension $72^{\circ} \mathrm{C}$ selama 20 detik, dan post extension $72^{\circ} \mathrm{C}$ selama 5 menit.

Analisis hasil amplifikasi PCR dengan elektroforesis. Sampel DNA hasil PCR diambil sebanyak $5 \mu$ dimasukkan dalam sumuran gel agarosa $1,5 \%$ yang telah dicampur dengan Etidium Bromida 0,5 $\mu \mathrm{l}$ dan sumuran gel terakhir dimasukkan ladder DNA 100 bp. Pita DNA diamati pada $U V$ transilluminator dan difoto menggunakan kamera dengan mode monokrom. Hasil yang sesuai target ukuran gen $L c y-b$ kemudian dikirim untuk proses sekuensing ke 1st Base DNA Sequencing Malaysia. Proses sekuensing bertujuan untuk memperoleh data yang memuat sekuen basa nukleotida gen lycopene beta cyclase.

Analisis data dengan Clustal $X$ dan Mega 6. Kekerabatan ketiga kultivar tomat hasil sekuensing dan sekuen tomat gene bank yang telah diperoleh dalam bentuk fasta, 
dilakukan proses alignment menggunakan software Clustal X. Selanjutnya dilakukan rekonstruksi pohon filogenetik untuk melihat kedekatan atau kekerabatan ketiga kultivar tomat dengan sekuen gen likopen kultivar tomat lain dari NCBI dan sekuen gen outgroup lain yaitu Capsicum annuum L. dengan menggunakan aplikasi software Mega
6 dengan menu Phylogeny, Contruct Test Neighbor joining Tree.

\section{HASIL}

Amplikon DNA gen $\boldsymbol{L} \boldsymbol{c y}$ - $\boldsymbol{b}$. Hasil amplifikasi PCR gen $L c y-b$ menghasilkan amplikon berukuran sebesar 301 bp (Gambar 2).

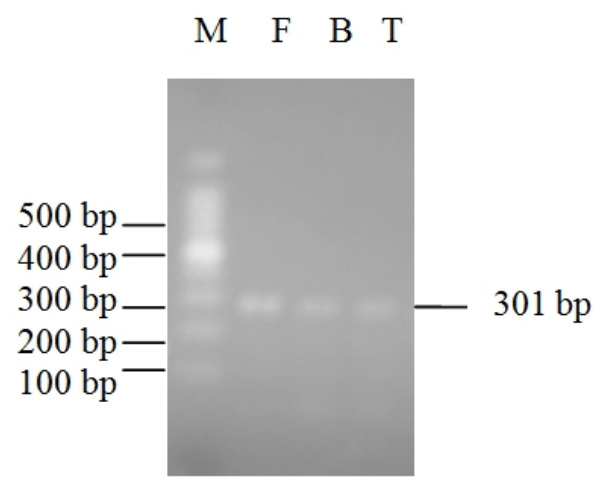

Gambar 2. Hasil amplifikasi DNA Lycopene beta cyclase pada gel Agarose 1,5\%. (Keterangan: B. Betavila F1, F. Fortuna F1, T. Tymoti F1; M: DNA marker 100 bp).

Alignment basa nukleotida kultivar Betavila F1, Fortuna F1 dan Tymoti F1 dengan sekuen tomat gene bank dan outgroup Capsicum annuum L. sepanjang 186 bp.

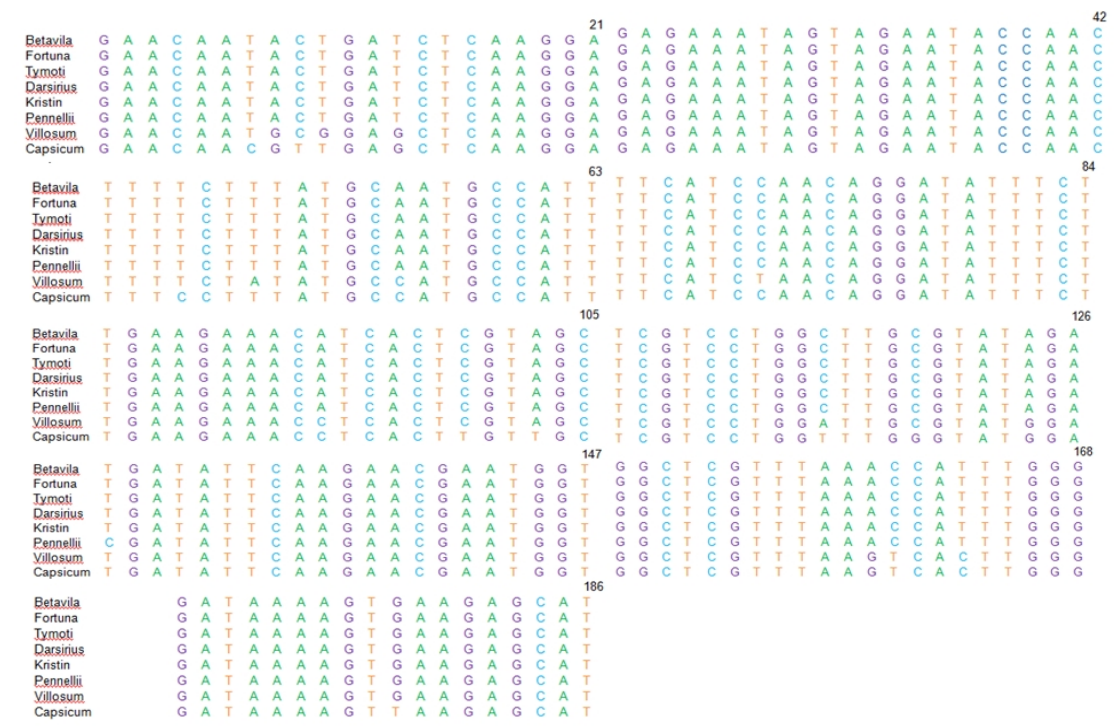

Gambar 3. Alignment ketiga kultivar tomat dengan sekuen tomat Darsirius, Kristin, Pennellii, Villosum dan outgroup Capsicum annuum kultivar Valensia.

Tabel 2. Mutasi transisi dan transversi pada varietas tomat Pennellii, Villosum dan Capsicum annuum kultivar Valensia

\begin{tabular}{llllllllllllll}
\hline Sampel & \multicolumn{10}{c}{ Mutasi transisi basa nukleotida ke- } \\
& 7 & 8 & 9 & 10 & 13 & 46 & 49 & 55 & 70 & 94 & 100 & 103 \\
\hline Betavila & $\mathrm{T}$ & $\mathrm{A}$ & $\mathrm{C}$ & $\mathrm{T}$ & $\mathrm{T}$ & $\mathrm{T}$ & $\mathrm{T}$ & $\mathrm{A}$ & $\mathrm{C}$ & $\mathrm{A}$ & $\mathrm{C}$ & $\mathrm{A}$ \\
\hline Fortuna & $\mathrm{T}$ & $\mathrm{A}$ & $\mathrm{C}$ & $\mathrm{T}$ & $\mathrm{T}$ & $\mathrm{T}$ & $\mathrm{T}$ & $\mathrm{A}$ & $\mathrm{C}$ & $\mathrm{A}$ & $\mathrm{C}$ & $\mathrm{A}$ \\
\hline
\end{tabular}




\begin{tabular}{lllllllllllll}
\hline Tymoti & T & A & C & T & T & T & T & A & C & A & C & A \\
\hline Darsirius & T & A & C & T & T & T & T & A & C & A & C & A \\
\hline Kristin & T & A & C & T & T & T & T & A & C & A & C & A \\
\hline Pennellii & T & A & C & T & T & T & T & A & C & A & C & A \\
\hline Villosum & T & G & C & G & G & T & A & C & T & C & C & A \\
\hline Capsicum & C & G & T & T & G & C & T & C & C & C & T & T \\
\hline Betavila & 115 & 119 & 124 & 127 & 159 & 160 & 163 & 178 & & \\
\hline Fortuna & C & C & A & T & A & C & T & G & & \\
\hline Tymoti & C & C & A & T & A & C & T & G & & \\
\hline Darsirius & C & C & A & T & A & C & T & G & & \\
\hline Kristin & C & C & A & T & A & C & T & G & & & \\
\hline Pennellii & C & C & A & T & A & C & T & G & & & \\
\hline Villosum & C & C & A & C & A & C & T & G & & & \\
\hline Capsicum & A & C & G & T & G & T & C & G & & & \\
\hline Betavila & T & G & G & T & G & T & C & T & & & \\
\hline Keterangan: Mutasi transisi dan transversi dengan huruf cetak tebal & & & & & & \\
\end{tabular}

Keterangan: Mutasi transisi dan transversi dengan huruf cetak tebal

Kekerabatan kultivar Betavila F1, Fortuna F1 dan Tymoti F1. Rekontruksi pohon filogenetik dibentuk berdasarkan hasil alignment antara sampel kultivar tomat
Betavila F1, Fortuna F1 dan Tymoti F1 dengan sekuen outgroup $C$. annuum kultivar Valensia.

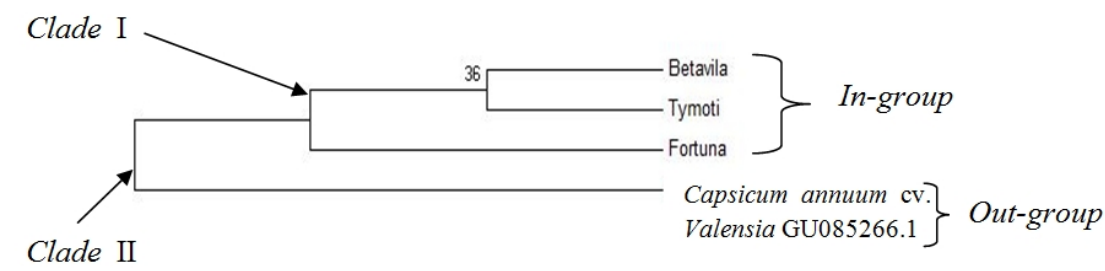

Gambar 4. Rekonstruksi pohon kekerabatan ketiga kultivar tomat dengan satu sekuen gene bank Capsicum annuum kultivar Valensia atas dasar gen Lcy-b menggunakan algoritme Neighbor Joining, model evolusi kimura 2 parameter dengan pengulangan boostrap 1000.

Tabel 3. Jarak genetik basa nukleotida DNA Lycopene beta cyclase ketiga kultivar tomat Betavila F1, Fortuna F1, dan Tymoti F1 dengan data base sekuen gene bank dan outgroup Capsicum annuum kultivar Valensia

\begin{tabular}{llllll}
\hline Species 1 & Species 2 & Distance & Species 1 & Species 2 & Distance \\
\hline Betavila & Fortuna & 0.000 & Kristin & Pennellii & 0.005 \\
\hline Betavila & Tymoti & 0.000 & Betavila & Villosum & 0.071 \\
\hline Fortuna & Tymoti & 0.000 & Fortuna & Villosum & 0.071 \\
\hline Betavila & Darsirius & 0.000 & Tymoti & Villosum & 0.071 \\
\hline Fortuna & Darsirius & 0.000 & Darsirius & Villosum & 0.071 \\
\hline Tymoti & Darsirius & 0.000 & Kristin & Villosum & 0.071 \\
\hline Betavila & Kristin & 0.000 & Pennellii & Villosum & 0.077 \\
\hline Fortuna & Kristin & 0.000 & Betavila & Capsicum & 0.098 \\
\hline Tymoti & Kristin & 0.000 & Fortuna & Capsicum & 0.098 \\
\hline Darsirius & Kristin & 0.000 & Tymoti & Capsicum & 0.098 \\
\hline Betavila & Pennellii & 0.005 & Darsirius & Capsicum & 0.098 \\
\hline Fortuna & Pennellii & 0.005 & Kristin & Capsicum & 0.098 \\
\hline Tymoti & Pennellii & 0.005 & Pennellii & Capsicum & 0.106 \\
\hline Darsirius & Pennellii & 0.005 & Villosum & Capsicum & 0.064
\end{tabular}




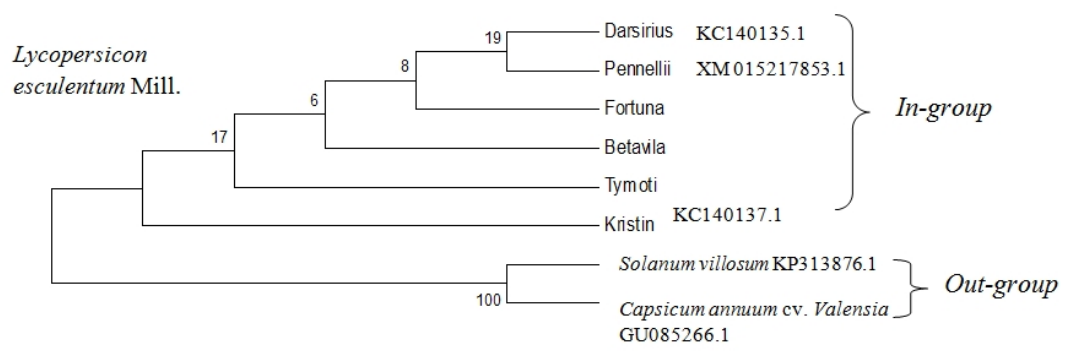

Gambar 5. Rekonstruksi pohon filogenetik dengan boostrap consensus tree

\section{PEMBAHASAN}

Alignment basa nukleotida kultivar Betavila F1, Fortuna F1 dan Tymoti F1 dengan sekuen tomat gene bank dan outgroup Capsicum annuum L. sepanjang 186 bp. Berdasarkan hasil aligment gen $L c y-b$ ketiga kultivar tomat tidak ditemukan perbedaan basa nukleotida (Gambar 3). Perbedaan basa nukleotida yang mengalami mutasi transisi yaitu pergantian basa purin $(\mathrm{A} / \mathrm{G})$ ke basa purin $(\mathrm{G} / \mathrm{A})$ atau basa pirimidin $(\mathrm{C} / \mathrm{T})$ ke basa pirimidin $(\mathrm{T} / \mathrm{C})$ (Wirdateti et al., 2013) dan mutasi transversi yaitu pergantian basa purin $(\mathrm{A} / \mathrm{G})$ ke basa pirimidin $(\mathrm{C} / \mathrm{T})$ atau sebaliknya basa pirimidin $(\mathrm{C} / \mathrm{T}) \mathrm{ke}$ basa purin (A/G) (Kino and Sugiyama, 2000) hanya ditemukan pada sekuen tomat lain yaitu varietas tomat Pennellii, Villosum dan $C$. annuum kultivar Valensia. Variasi mutasi transisi dan transversi basa nukleotida tersaji pada Tabel 2.

Berdasarkan Tabel 2 yang menunjukkan mutasi transisi dan transversi pada varietas tomat Pennellii, Villosum dan Capsicum annuum kultivar Valensia, varietas tomat Pennellii menunjukkan mutasi transisi hanya pada basa nukleotida ke-127 sehingga tidak mengalami banyak perubahan basa nukleotida. Varietas tomat Villosum menunjukkan mutasi transisi pada basa nukleotida ke-8, 70, 124, 159, 160, 163, dan mutasi transversi pada basa nukleotida ke-10, 13, 49, 55, 94, dan 115. Jumlah perubahan basa nukleotida sebanyak 12 basa nukleotida. Kemudian C. annuum kultivar Valensia yang mengalami mutasi transisi terdapat pada basa nukleotida ke-7, 8, 9, 46, 100, 115, 124, 159, 160, dan 163. Mutasi transversi C. annuum kultivar Valensia terdapat pada basa nukleotida ke-13, 55, 94, 103, 119, dan 178.
Mutasi transisi dan transversi pada $C$. annuum kultivar Valensia sebanyak 16 basa nukleotida.

Pohon filogenetik pada Gambar 4 terdapat nilai boostrap yang menunjukkan pengulangan sampling untuk memperoleh rekonstruksi pohon filogenetik yang benar. Hal ini sesuai dengan pernyataan Dharmayanti, (2011), analisis boostrap adalah metode yang menguji seberapa baik set data model yang bertujuan untuk memperkecil kesalahan dalam merekonstruksi pohon filogenetik dengan proses sampling ulang sehingga dapat teruji validitas rekonstruksi pohon filogenetik dan topologi pohon filogenetik yang diprediksi menjadi signifikan jika set data resampled berulangkali bernilai $>70 \%$ yang memprediksi cabang-cabang yang sama. Meskipun pohon filogenetik yang terbentuk memiliki nilai boostrap kurang dari $70 \%$, tetapi topologi pohon filogentik yang terbentuk sudah benar karena Capsicum annuum kultivar Valensia menjadi kelompok outgroup. Pohon filogenetik (Gambar 4) membentuk dua clade yaitu clade I terdiri dari kultivar Betavila F1, Tymoti F1, dan Fortuna F1, subclade kultivar Betavila F1 dan Tymoti $F 1$ yang berkumpul dalam kelompok ingroup dan clade II yaitu $C$. annuum kultivar Valensia yang menjadi kelompok outgroup. Subclade kultivar Betavila F1 berkerabat dekat dengan subclade kultivar Tymoti F1 dan kultivar Fortuna F1 berkerabat dekat dengan subclade kultivar Tymoti F1, meskipun memiliki panjang cabang pohon filogenetik yang lebih jauh dari kedua kultivar subclade dari dasar pohon. Hal ini berarti sejak terjadinya percabangan dari nenek moyang bersama, kultivar Betavila F1 dengan kultivar Tymoti Fl keduanya memiliki laju perubahan 
genetik yang sedikit yang direfleksikan dengan panjang cabang pohon filogenetik yang lebih dekat ke dasar pohon dibandingkan dengan kultivar Fortuna F1 yang memiliki laju perubahan genetik yang sedikit banyak dengan panjang cabang pohon filogenetik yang jauh dari dasar pohon.

Spesies luar C. annuum kultivar Valensia memiliki laju perubahan genetik yang banyak ditunjukkan dengan panjang cabang pohon filogenetik yang lebih jauh dari dasar pohon filogenetik dibandingkan dengan kelompok ingroup sehingga dikelompokkan menjadi kelompok outgroup. Hal ini sesuai dengan pernyataan Campbell et al. (2008), panjang cabang pohon filogenetik dapat merefleksikan jumlah perubahan genetik yang terjadi seperti dicontohkan panjang cabang pohon filogenetik dari dasar pohon ke mencit lebih pendek dibandingkan dengan panjang cabang filogenetik menuju spesies luar lalat Drosophila yang menyiratkan sejak terjadinya divergensi dari nenek moyang bersama, lebih banyak perubahan genetik yang terjadi pada garis keturunan lalat Drosophila daripada garis keturunan mencit.

Kekerabatan ketiga kultivar tomat berdasarkan sekuen tomat gene bank dan outgroup Capsicum annuum L. Pohon filogenetik pada Gambar 5 yang terbentuk berdasarkan hasil alignment dan perbedaan jarak genetik (Tabel 3) menunjukkan kultivar Fortuna F1 berkerabat dekat dengan sekuen tomat gene bank varietas Pennellii dan kultivar Darsirius karena memiliki panjang cabang pohon filogenetik yang dekat dengan dasar pohon sehingga terdapat perbedaan jarak genetik yang sedikit dan kultivar tomat Fortuna F1 lebih maju dibandingkan dengan kultivar Betavila F1. Kemudian kultivar Betavila F1 berkerabat jauh dengan sekuen tomat lain dari data base, tetapi kultivar Betavila $F 1$ berkerabat dekat dengan kultivar Fortuna $F 1$ yang ditunjukkan panjang cabang kultivar Betavila F1 lebih dekat dengan kultivar Fortuna Fl dibandingkan dengan panjang cabang yang lebih jauh dengan kultivar Tymoti F1 dan kultivar Betavila F1 lebih maju dibandingkan dengan kultivar Tymoti F1.
Berdasarkan pada Gambar 5 kultivar Tymoti F1 berkerabat dekat dengan sekuen tomat gene bank kultivar Kristin karena memiliki sedikit perbedaan jarak genetik yang direfleksikan dengan panjang cabang pohon filogenetik yang dekat dengan dasar pohon. Kultivar Tymoti F1 tergolong kultivar yang lebih primitif dibandingkan dengan kultivar Betavila $F 1$ yang ditunjukkan dengan panjang cabang pohon filogenetik yang jauh dari dasar pohon.

Kekerabatan ketiga kultivar tomat lokal pada Gambar 5 menunjukkan hubungan kekerabatan yang jauh dengan outgroup sekuen tomat Villosum dan C. annuum kultivar Valensia yang ditunjukkan dengan panjang cabang pohon filogenetik lebih jauh dari dasar pohon filogenetik dan jarak genetik yang banyak dibandingkan dengan kultivar tomat lain.

Sekuen tomat Villosum menjadi outgroup dan berkerabat dekat dengan $C$. annuum kultivar Valensia karena memiliki jarak genetik yang tidak berbeda jauh (Tabel 3) dan didukung dengan nilai Boostrap 100\%.

Ketiga kultivar tomat lokal yaitu Betavila $F 1$, Fortuna F1, dan Tymoti F1 yang bergabung dengan sekuen tomat Darsirius, Pennellii, dan Kristin memiliki nilai Boostrap kurang dari $70 \%$. Nilai boostrap diantara 70\%-100\% menunjukkan percabangan pohon filogenetik tidak akan berubah. Sebaliknya, jika nilai boostrap kurang dari $70 \%$ maka peluang terjadinya susunan percabangan sangat tinggi dan ketika dilakukan analisis pohon filogenetik pohon filogenetik yang dibentuk masih dapat berubah-ubah (Simpson, 2006; Rukmana, 2015). Meskipun demikian, percabangan pohon filogenetik yang terbentuk dari ketiga kultivar tomat lokal tersebut dengan sekuen tomat Darsirius, Pennellii, dan Kristin dapat dipercaya berdasarkan perbedaan jarak genetik pada Tabel 3 yang sedikit, bernilai 0.000 yang berarti tidak ada perbedaan jarak genetik.

Studi sebelumnya menurut Rosati et al., (2000), modifikasi gen $L c y$ - $b$ dapat meningkatkan level beta karoten sampai tujuh kali di bawah kontrol promoter $P d s$ (phytoene desaturase). Akhirnya keragaman gen $L c y-b$ 
pada penelitian ini diharapkan dapat berkontribusi sebagai strategi transgenik untuk memodifikasi kandungan karotenoid pada buah tomat.

\section{KESIMPULAN}

1. Kultivar Betavila F1 berkerabat dekat dengan kultivar Tymoti F1 dan kultivar Fortuna F1 berkerabat dekat dengan kultivar Tymoti F1.

2. Kultivar Fortuna Fl berkerabat dekat dengan sekuen gene bank kultivar Darsirius dan varietas Pennelli. Kultivar Betavila F1 berkerabat jauh dengan tomat lain kultivar Darsirius, Kristin dan varietas Pennelli dan berkerabat dekat dengan kultivar Fortuna F1. Kultivar Tymoti $F 1$ berkerabat dekat dengan kultivar Kristin. Ketiga kultivar tomat berkerabat jauh dengan spesies luar $C$. annuum kultivar Valensia.

3. Perbedaan basa nukleotida tidak ditemukan pada ketiga kultivar tomat dan hanya ditemukan pada sekuen tomat varietas Pennellii yang mengalami mutasi transisi sebanyak 1 basa nukleotida. Perbedaan basa nukleotida juga ditemukan pada kelompok outgroup varietas Villosum yang mengalami mutasi transisi dan mutasi transversi sebanyak 12 basa nukleotida dan $C$. annuum kultivar Valensia yang mengalami mutasi transisi dan mutasi transversi sebanyak 16 basa nukleotida.

\section{DAFTAR PUSTAKA}

Araujo AH, Fonseca MEDN, Boiteux LS. 2007. Nucleotide Diversity of a Major Carotenoid Biosynthetic Pathway Gene in Wild and Cultivated Solanum (Section Lycopersicon) Species. Brazilian Journal Plant Physiology 19 (3): 233-237.

Bramley PM. 2012. Regulation of Carotenoid Formation during Tomato Fruit Ripening and Development. Journal of Experimental Botany 53 (377): 21072113.

Breemen RBV and Pajkovic N. 2008. Multitargeted Therapy of Cancer by
Lycopene. Journal Cancer Letters 269 (2): 339-351.

Campbell NA, Reece JB, Urry LA, Cain ML, Wasserman SA, Minorky PV, Jackson RB. 2008. Biologi Edisi 8, Jilid 2. Jakart: Erlangga. hal.101-105.

Dalal M, Chinnusamy V, Bansal KC. 2010. Isolation and Functional Characterization of Lycopene $\beta$-cyclase (CYC-B) Promoter from Solanum habrochaites. Journal Biomed Central Plant Biology 10: 61 .

Dharmayanti I. 2011. Filogenetika Molekular: Metode Taksonomi Organisme Berdasarkan Sejarah Evolusi. Jurnal Wartazoa 21 (1): 1-10.

El-Raey MA, Ibrahim GE, Eldahshan OA. 2013. Lycopene and Lutein: A Review for Their Chemistry and Medicinal Uses. Journal of Pharmacognosy and Phytochemistry 2 (1): 245-254.

Giorio G, Yildirim A, Stigliani AL, D'Ambrosio C. 2013. Elevation of Lutein Contetnt in Tomato: A Biochemical Tugof-War Between Lycoepene cyclase. Journal Metabolic Engineering 20: 167176.

Hirschberg J. 2001. Carotenoid Biosynthesis in Flowering Plants. Journal and Physiology Metabolism 4: 210-218.

Kino K and Sugiyama H. 2000. GC-CG Transversion Mutation Might be Caused by 8-Oxoguanine Oxidation Product. Journal Nucleic Acid Symposium 44: 139-140.

Ronen G, Carmel-Goren L, Zamir D, Hirschberg. 2000. An Alternative Pathway to $\beta$-Caroten Formation in Plant Chromoplast Discovered by Map-Based Cloning of Beta and Old-Gold Color Mutation in Tomato. Journal Proceedings of The National Academy of Sciences 97 (20): 11102-11107.

Rosati C, Aquilani R, Dharmapuri S, Pallara $\mathrm{P}$, marusic $\mathrm{C}$, Tavazza $\mathrm{R}$, Bouvier $\mathrm{F}$, Camara B, Giuliano G. 2000. Metabolic Engineering of beta-carotene and Lycopene Content in Tomato Fruit. The Plant Journal 24 (3): 413-419. 
Rukmana S. 2015. Perbandingan Sekuen Kapang Trichoderma sp. Berdasarkan Internal Transcribed Spacer (ITS) rDNA Dengan Menggunakan Database NCBI. [Skripsi]. Malang: Fakultas Sains dan Teknologi, UIN Maulana Malik Ibrahim. hal. 54.
Simpson MG. 2006. Plant Systematic. California: Elsevier Academic Press.

Wirdateti, Semiadi G dan Yulianto. 2013. Identifikasi Trenggiling (Manis javanica) Menggunakan Penanda Cytochrome B Mitokondria DNA. Jurnal Veteriner 14 (4): 467-474. 